\title{
HYPERELASTIC-MATERIAL CHARACTERIZATION: A COMPARISON OF MATERIAL CONSTANTS
}

\author{
KARAKTERIZACIJA HIPERELASTIČNOSTI MATERIALA: \\ PRIMERJAVA MED MATERIALNIMI KONSTANTAMI
}

\author{
Rohitha Keerthiwansa*, Jakub Javorik, Jan Kledrowetz \\ Department of Production Engineering, Faculty of Technology, Tomas Bata University in Zlin, Vavrečkova 275, \\ 76001 Zlin, Czech Republic \\ Prejem rokopisa - received: 2019-07-16; sprejem za objavo - accepted for publication: 2019-11-04
}

doi:10.17222/mit.2019.161

\begin{abstract}
Data fitting is an essential part of obtaining material constants for hyperelastic models. However, due to inadequate experimental data, a single-data set, i.e. uniaxial data, is often used for fitting. Despite a frequent use of this method, it is proven that it provides an inaccurate forecast for a characterization. Therefore, as an alternative method, combined-data fitting is usually recommended. In this research, material constants calculated through two different data-fitting methods were evaluated in terms of dispersion. First, material constants were obtained by taking the average of two single-data-set fitted constants (the uniaxial and biaxial data). The second method used the combined-data fitting to find the material constants. Using the constants found, biaxial and uniaxial curves were drawn for each case. For this purpose, three models, the Mooney, Ogden and Yeoh model, were selected. When considering the Mooney model, the averaged method seems not to show a sufficient improvement to the biaxial curve. The Yeoh model reacts equally to both methods, while the Ogden model seems not to be applicable to the averaged method.

Keywords: elastomers, hyperelasticity, material constants, data fitting

Obdelava eksperimentalnih podatkov je ključni del določitve materialnih konstant, ki jih uporabljamo v modelih za hiper-elastičnost materialov. Vendar pa se zaradi neustreznih eksperimentalnih podatkov uporablja enovit set podatkov, to je podatek dobljen pri enoosnem obremenjevanju. Kljub pogosti uporabi te metode je dokazano, da le-ta omogoča nenatančno napoved oz. karakterizacijo. Zato se običajno priporoča alternativna metoda, pri kateri dodatno uporabljamo "fitanje« oz. obdelavo in prilagajanje podatkov. V prispevku avtorji izračunavajo materialne konstante $\mathrm{z}$ dvema različnima metodama fitanja podatkov in ju vrednotijo glede na razpršenost. V prvem primeru so avtorji materialne konstante določili z določitvijo povprečja dveh enovitih setov podatkov fitanja konstantnih vrednosti (vrednosti dobljene pri enoosnem in dvoosnem preizkusu). V drugem primeru pa so, da bi določili materialne konstante, uporabili kombinirano fitanje podatkov. Z uporabo ugotovljenih konstant so izrisali eno in dvoosne krivulje za vsak primer posebej. V ta namen so uporabili oz. izbrali tri različne modele: Mooneyev, Ogdenov in Yeohov model. Izračun z Mooneyevim modelom je pokazal, da metoda povprečenja ne predstavlja zadovoljive izboljšave za dvoosno krivuljo. Yeohov model je reagiral podobno pri obeh metodah, medtem ko se Ogdenov model zdi uporaben za metodo povprečenja.

Ključne besede: elastomeri, hiper-elastičnost, materialne konstante, obdelava oz. fitanje podatkov
\end{abstract}

\section{INTRODUCTION}

Data fitting is an integral part of finding material constants for a selected hyperelastic model in the mechanical characterization of elastomers. Many a time, it is observed that due to various reasons, material characterization was done with a single-data set. However, it is established that the use of one data set for the fitting leads to inaccuracies. In order to avoid this, combined data fitting with two or more data sets is recommended. When there are more than one data set and combined data fitting can be considered as the preferred solution. However, there is another possibility of fitting each data set separately to obtain the averaged values for the much needed material constants. In this work, we intend to investigate this additional method for its suitability for an application related to the three material models.

*Corresponding author's e-mail:

keerthiwansa@utb.cz (Rohitha Keerthiwansa)
The topic of material characterization is very popular in the scientific community and, consequently, there are many published materials on this theme. Therefore, it is appropriate to mention some of the works we went through when preparing our research.

R. W. Ogden ${ }^{1}$ experimented with the biaxial behaviour and improved the model as a modification to the Valanis-Landel ${ }^{2}$ hypothesis. E. H. Twizell and R. W. $\operatorname{Ogden}^{3}$ improved the established relationship between the theory and experiment by methodically optimizing the material-constant calculation. D. A. Morrow et al. ${ }^{4}$ discussed the elastomer curve fitting the evaluation techniques. R. W. Ogden et al. ${ }^{5}$ also experimented extensively with the curve fitting with the Ogden model. G. Marckmann and E. Verron ${ }^{6}$ did a comprehensive study of material models too.

\section{EXPERIMENTAL PART}

The Treloar data $^{7}$ are frequently used in hyperelastic-material-characterisation research. Hence, two of 
these data sets, uniaxial and biaxial-tension data were used for this material-constant-comparison experiment. For the material-characterization part of the work, three models, namely, the Mooney, Ogden and Yeoh model were selected.

After selecting the model, using a uniaxial-data set, data fitting was done. For the data fitting, the least squares principal was used. Consequently, the same procedure was followed for the biaxial-data set. The material constants obtained were then added and the average value was calculated for each material constant. In the second part of the experiment, for the same model, combined data fitting was done using the uniaxial and biaxial data simultaneously. The procedure was carried out for all three models. With the material-constant values in place for each model, both uniaxial and biaxial graphs were drawn for the two experimental cases, averaged and combined. As a reference, only uniaxial-data fitted curves were also plotted in the same graph.

\section{RESULTS}

Results of the combined-data fitting and averaged material constants are given in Table 1. In the table, the first column lists the three considered models, while the second column gives the respective material-constant abbreviations. The last two columns of the table list the material-constant values for two separate cases, the averaged and combined one, respectively.

Based on these material constants, uniaxial and biaxial curves were drawn for the mentioned three models.

Table 1: Material constants for the three models

\begin{tabular}{|c|c|c|c|}
\hline \multicolumn{2}{|c|}{} & \multicolumn{2}{c|}{ Treloar data } \\
\cline { 3 - 4 } \multicolumn{2}{|c|}{} & Averaged & Combined \\
\hline \multirow{3}{*}{ Mooney } & $\mathrm{C} 10$ & 0.2138895 & 0.186701 \\
\cline { 2 - 4 } & $\mathrm{C} 01$ & -0.04897777 & 0.0032429 \\
\hline \multirow{3}{*}{ Ogden } & $\mu 1$ & 0.17032095 & -107.906 \\
\cline { 2 - 4 } & $\alpha 1$ & 1.31808 & -0.0064045 \\
\cline { 2 - 4 } & $\mu 2$ & 27.4163585 & 0.0244768 \\
\cline { 2 - 4 } & $\alpha 2$ & 1.2744614 & 3.58976 \\
\hline \multirow{3}{*}{ Yeoh } & $\mathrm{C} 10$ & 0.1900445 & 0.182867 \\
\cline { 2 - 4 } & $\mathrm{C} 20$ & -0.00148556 & -0.0012875 \\
\cline { 2 - 4 } & $\mathrm{C} 30$ & $4.24484 \mathrm{E}-05$ & $3.71 \mathrm{E}-05$ \\
\hline
\end{tabular}

The single-data set is used for data-fitted curves, only uniaxial and only biaxial curves are also given in each graph as references. These graphs are shown in Figures 1, 2 and 3.

\section{DISCUSSION}

When examining the Mooney-Rivlin biaxial graphs given in Figure 1, the averaged-material-constant-driven curve seems to have improved the referenced only- uniaxial-data fitted curve. However, it still cannot be accepted as the correct form of the curve since the typical location and shape of the biaxial curve do not prevail. With regard to the uniaxial curves, it can be observed from the figure that, for the model, both the averaged and combined curves depict somewhat similar results. Contrary to the Mooney-Rivlin model, the Yeoh model given in Figure 2 shows almost the same results for both the uniaxial and biaxial curves for the two cases discussed. The referenced only-uniaxial-data fitted curve

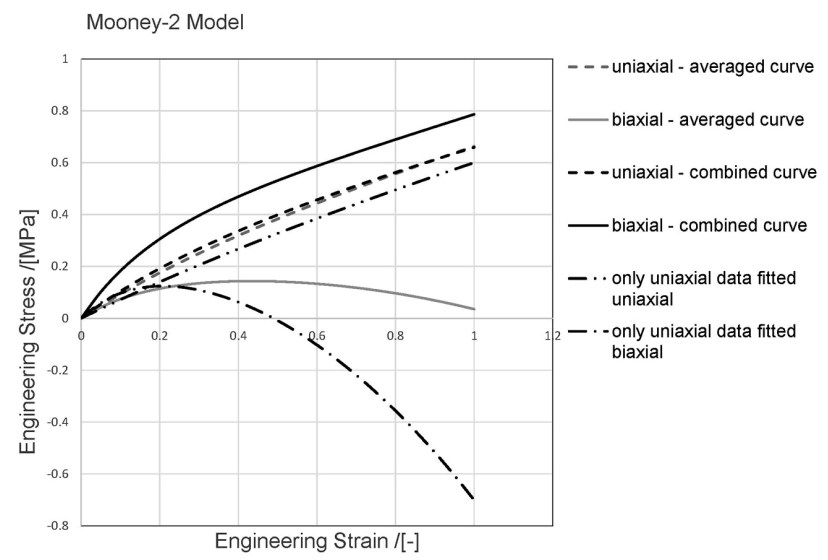

Figure 1: Mooney-2 model curves

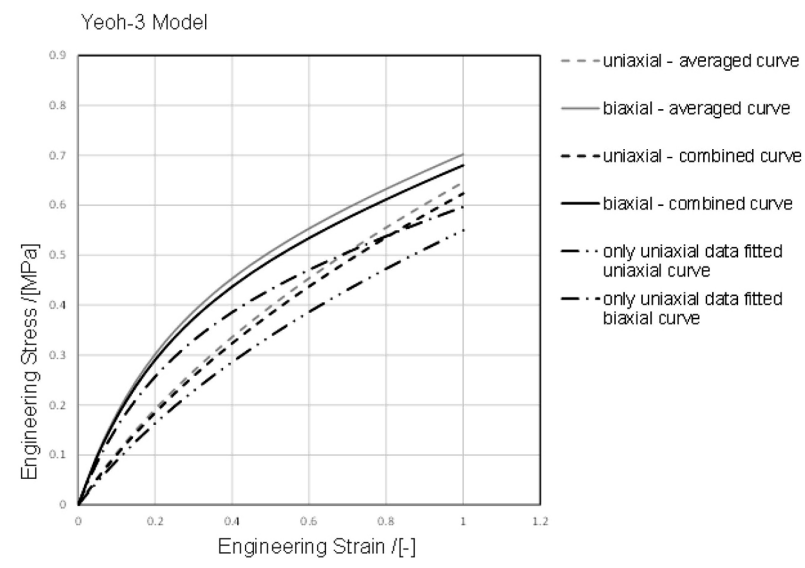

Figure 2: Yeoh-3 model curves

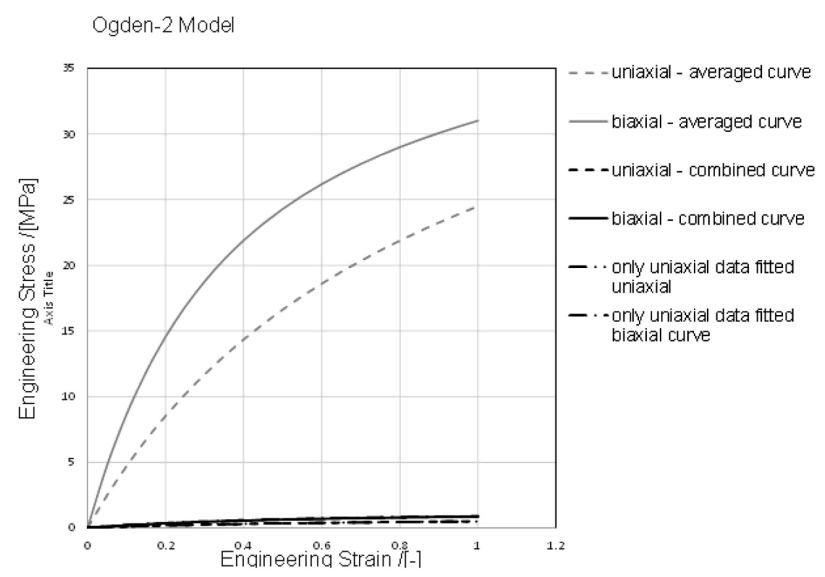

Figure 3: Ogden-2 model curves 
seems to be lagging behind the previously discussed curves. As a material model, the Ogden model is different from the other two models. When considering it, unlike the other two, this model is described directly through stretch ratios, instead of invariants. When observing Figure 3, drastic changes are visible. These might have been due to the factor discussed. However, considering it, in order to construct a material model, averaged constant values do not seem to be the right particular case.

\section{CONCLUSIONS}

In order to complete a hyperelestic material model, model constants need to be calculated. In this experiment, two methods of calculating material constants were studied. With the first method, material constants were calculated by taking the average from the constant values obtained through a single-data-set fitting exercise using both uniaxial and biaxial data. The second method used the combined-data fitting to obtain the material constants. The two methods were then tested with three models. According to the results, the Mooney-Rivlin model is best with the combined-data-fitted constant values. The Yeoh model seems not to differentiate between the two methods. According to the results, the averaged method cannot be used for the Ogden model.

\section{Acknowledgment}

This work and the project were realised with the financial support of an internal grant of TBU in Zlin, No. IGA/FT/2019/001, funded from the resources for specific university research.

\section{REFERENCES}

${ }^{1}$ R. W. Ogden, Biaxial deformation of rubber-like solids: comparison of theory and experiment, J. Phys. D: Appl. Phys., 12 (1979)

${ }^{2}$ R. S. Rivlin, The Valanis-Landel Strain-Energy Function, J. of Elasticity, 73 (2003), 291-297

${ }^{3}$ E. H. Twizell, R. W. Ogden, Non-linear optimization of the material constants in Ogden's stress-deformation function for incompressible isotropic elastic materials, J. Austral. Math. Soc., 24 (1983) 4, 424-434, doi:10.1017/S0334270000003787

${ }^{4}$ D. A. Morrow, T. H. Donahue, G. M. Odegard, K. R. Kaufman, A method for assessing the fit of a constitutive material model to experimental stress-strain data, J. Comput. Methods Biomech. Biomed. Engin., 13 (2010) 2, 247-256, doi:10.1080/ 10255840903170686

${ }^{5}$ R. W. Ogden, G. Saccomandi, I. Sgura, Fitting hyperelastic models to experimental data, Computational Mechanics, Springer-Verlag 2004, doi:10.1007/S00466-004-0593-y

${ }^{6}$ G. Marckmann, E. Verron, Comparison of hyperelastic models for rubber-like materials, J. Rubber Chemistry and Technology, American Chemical Society, 79 (2006) 5, 835-858

${ }^{7}$ X. Li, Y. Wei, Classic strain energy functions and constitutive tests of rubber-like materials, J. Rubber Chemistry and Technology, 88 (2015) 4, doi:10.5254/rct.15.84879 